\title{
Survey and Modelling for a Theoretical Reconstruction
}

\author{
Cecilia Bolognesi \\ Fausta Fiorillo
}

Abstract

The research focuses on the analysis and studies of a UNESCO site for which a major survey is underway by analysing its vaults geometry. The research is based on historical documents, previous reconstruction, actual 3D digital survey. The aim is to identify the ideal best fitting shapes that can represents the real architectural geometry of some of the vaults of the complex, where 3D models derived from laser scanner and/or photogrammetric measurements prove to be a very useful 'instrument' for the geometrical and constructive studies.

At present there are several studies that demonstrate how the productive integration between the classical geometrical constructions and 3D data allows the understanding of the architecture at various levels, for example: identifying common design techniques in a certain era, here in the passage between Romanic and Renaissance Era, developing constructive analysis etc. Current research tries to use this type of data also to develop structural behaviour analysis using the 3D model for the finite element process. Our method contemplates geometric reconstructions using different data sets obliged by necessity: some parts of the complex do not exist anymore, others have been reconstructed on previous grounds, others existing in their original shape have given the possibility to be surveyed now. The result is a first overview as a starting point to be deepened for the better knowledge of our Cultural Heritage, its history and construction across centuries.

Keywords

geometry, survey, vaults, modelling, Renaissance.

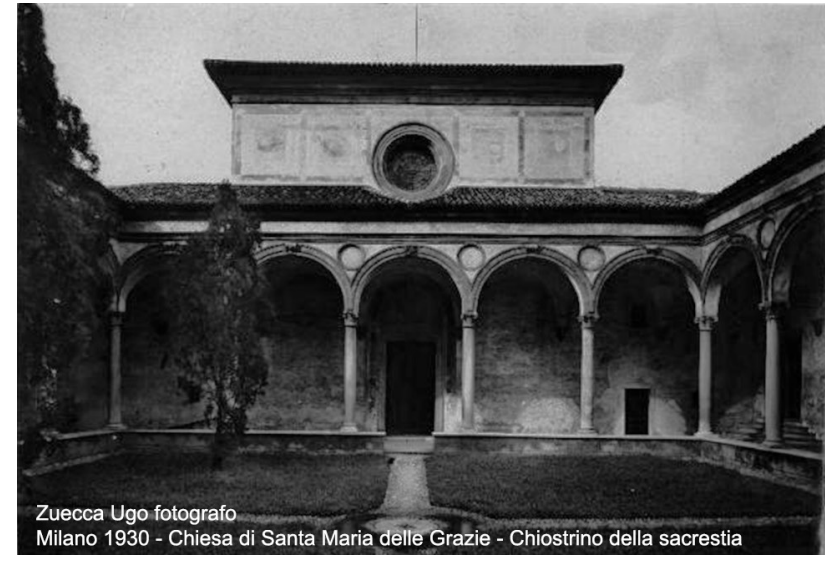

139
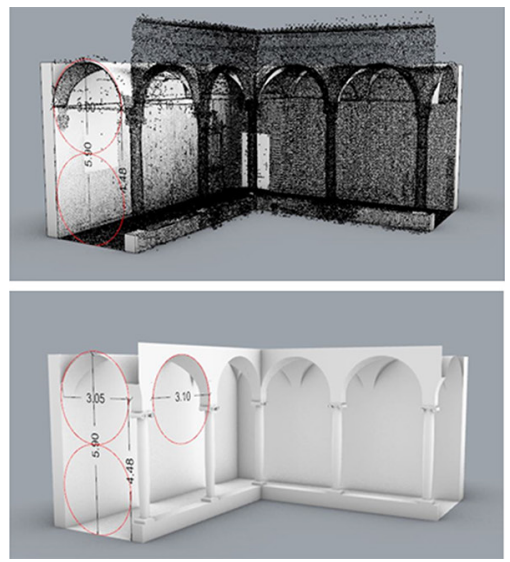

doi.org/ / 0.3280/oa-548.9 


\section{The case study}

The case study concerns a specific analysis regarding the development and construction of the convent of Santa Maria delle Grazie in Milan, whose first news deals with a building program of a convent complex by the friars of the Dominican order starting in I460, on a previous military camp with the presence of an ancient chapel dedicated to the Holy Virgin. The program of the construction respected the parameters given by the needs and customs of the order. The building of the church was realized from 1466 to 1490 on a project by Guiniforte Solari, while the convent was almost completed in 1469 at least in its main parts at the ground floor [Mezzanotte, Bascapè 1968]. The church was accompanied by a sacristy built according to the layout of the old Madonna delle Grazie chapel and the convent with a first cloister designed to bury dead, the chapter room, the refectory, the dormitory, the cells of the friars. Around these, the project included other cloisters to organize services.

The first stone placed of the convent in 1463 refers to the chapter room covered with vaulted ceilings and aligned with the walls of the old chapel. In I488, the refectory was completed on the west side. The cells were then added to complete the cloister of the Dead and then the large cloister.

The history of the complex is complicated and several specific treatments has deserved. What matters here is the architectural layout; apparent references to the Lombard Gothic present in the church are accompanied by forms of a sober Milanese Renaissance in some part of the complex. Both of them share the same fate: the huge bombing that in 1943 destroyed a large part of the complex, forcing various efforts for the philological reconstruction of some parts of it.

Two important documents support us in the morphological studies of the convent: some works done by Luca Beltrami at the end of the nineteenth century and the extensive survey measured by Giandomenico Pica in 1937 [Pica, Portaluppi 1937].

Fig. I. Est-West section on the Chiostro delle Rane, Chapter Room, library, Chiostro dei Morti, refectory (A. Pica survey).

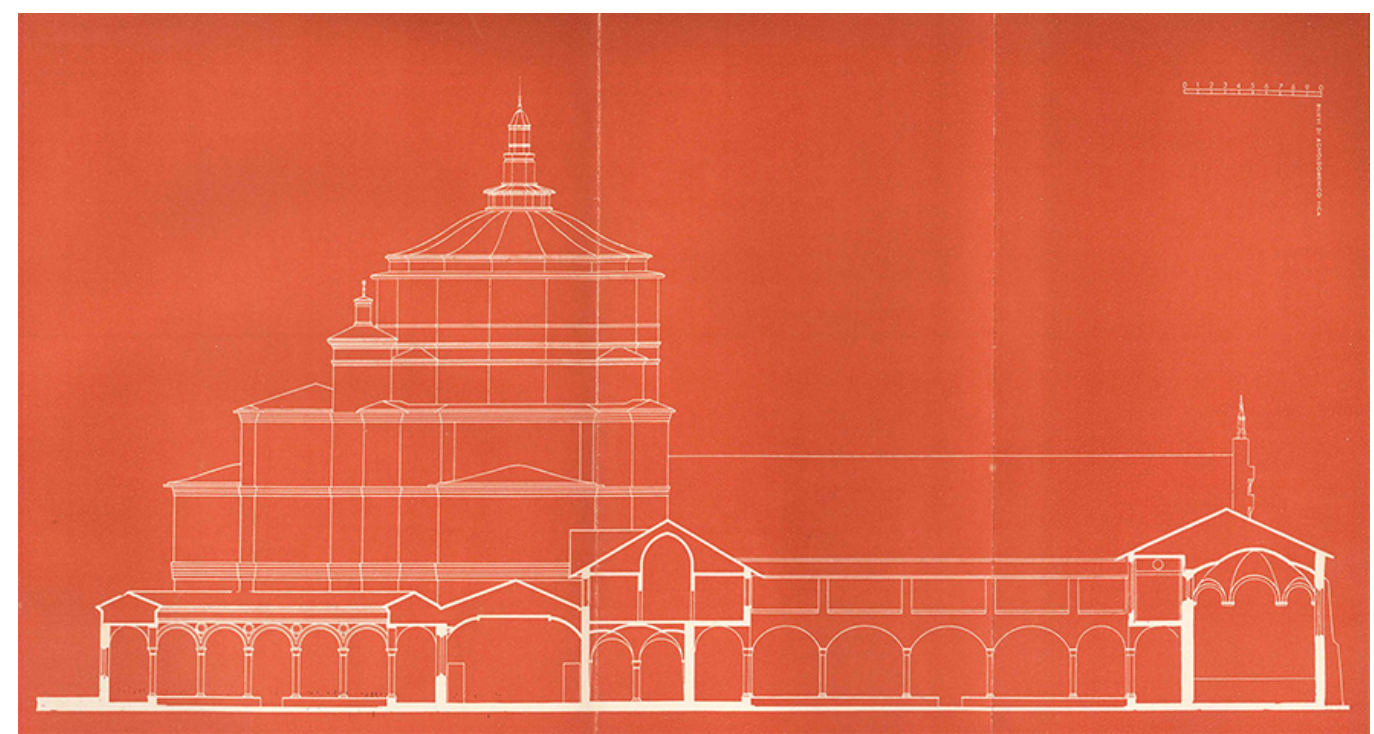

\section{Related works}

After previous works of the authors dealing with the survey of the complex [Bolognesi, Fiorillo 2019], this paper aims to identify the ideal best fitting shape that can represent the architectural geometry of some vaulted parts of it, to understand morphological choices of architecture and construction. 3D models derived from laser scanner and/or photogrammetric measurements prove to be a very useful instrument for the geometrical and 
constructive studies of vaults [lannizzaro et al. 2012] and many previous papers can be considered as positive method indicators of this methodology.

The productive integration between the classical geometrical constructions [Calvo López, Rabasa Díaz 2016] and this 3D data [Corazzi, Bertacchi 20I5] allows the understanding of the architecture at various levels, for example: developing constructive analysis [Navarro Camallonga, Rabasa Diaz 2018] or identifying common design techniques [López -Mozo, Senent-Domínguez 20 I7]. Current research tries to use this type of data also to develop structural behaviour analysis using the 3D model for the finite element process [Tucci et al. 2019]. Other studies refer more precisely to a research for generation of the shape derived from geometric analyses, supported when possible by survey digital tools [Capone et al. 20 I5]; others constitute a knowledge base to recognize and interpret the geometric structure of the vaults in certain historical times [Spallone 2019].

\section{The reconstruction from historical document: cross vault on a square layout}

Due to the architectural history of the convent and its transformations, it was necessary to identify different workflow linked to the modelling of the geometry of the vaulted space. Each of which gives rise to a different study even if in the geometric field: I) modelling from photographic material without the specific support of direct measurements, but using derived metric observation from historical technical drawings; 2) modelling supported by photographic documents of the previous building and existing surveyed perimeters of them; 3) modelling on a survey from point cloud and reconstruction with an accuracy level equal to the scale $1: 5$.

The first reconstruction observed concerns the vaulted rooms of the library of the convent that according to the writings of Gattico [Gattico 2004] is dated to I 480. The construction of the Chiostro dei Morti on which the library overlooked has always been affected by the lack of a unitary conception to configure the construction works and expansion over decades from I 464 until I 480 when the building was erected, remarkably detached from the adjacent bodies that contained the dormitory.

The library is located on the upper floor of this and has a clear consonance with the reference models such as the Malatesta Library of Cesena or the archetype of Michelozzo of San Marco in Florence. Although it is not a specific object of the Pica survey of 1938, dedicated primarily the Solariana Church and the Bramante apse, his survey offers us a view of the section of the rooms on the northern side of the cloister which include the three-nave library on the first floor, perhaps originally a single room.

The same survey note the height of the building at $10.20 \mathrm{~m}$ in the eaves, almost as if the Pica wanted to underline the actual difference in height between this construction and the others wings of the Chiostro dei Morti on two sides only on the ground floor. In addition to these findings, there are some photographic documents but there is no certainty of constructions on existing perimeters; the modelling carried out starts from the measurements made on the presumed base perimeter and from the photographic survey found in superintendence archives.

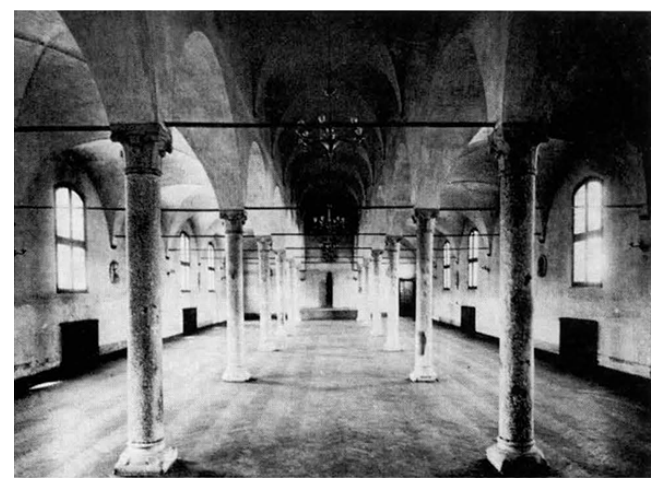


The structure hypothesized is a typical Roman cross vault on a square system consisting of the intersection of two bearing barrel vaults where the corners of the diagonal arches are the result of the intersection of the two barrel vaults. The construction of the vaults of the library coincides with the beginning of the period of humanism in Milan, which occurs with the transfer of power between the Visconti and the Sforza in the mid-fifteenth century.

The construction of the church by Solari a few years earlier follows the consolidated northern Gothic tradition of the basilica with three naves, low and wide, separated by stone columns, covered by cross vaults with creases, supported by leaf capitals. However, we are in another era.

Bramante arrived in the capital exactly one year before the construction of the library. The structure of the strictly cylindrical vault places the key of the arches of the barrel vaults on the same level.

The slight dimensional difference between the sides of the base square, which make them rectangular in the survey by Pica for a difference of a few centimetres, means that one of the two arches of the single module of the span is necessarily raised and consequently it creates a light elliptical profile. In common, the two cylinders have a tangent plane, which ensures the flatness of the curves of the ribs to allow the two key lines to remain on the same plane.

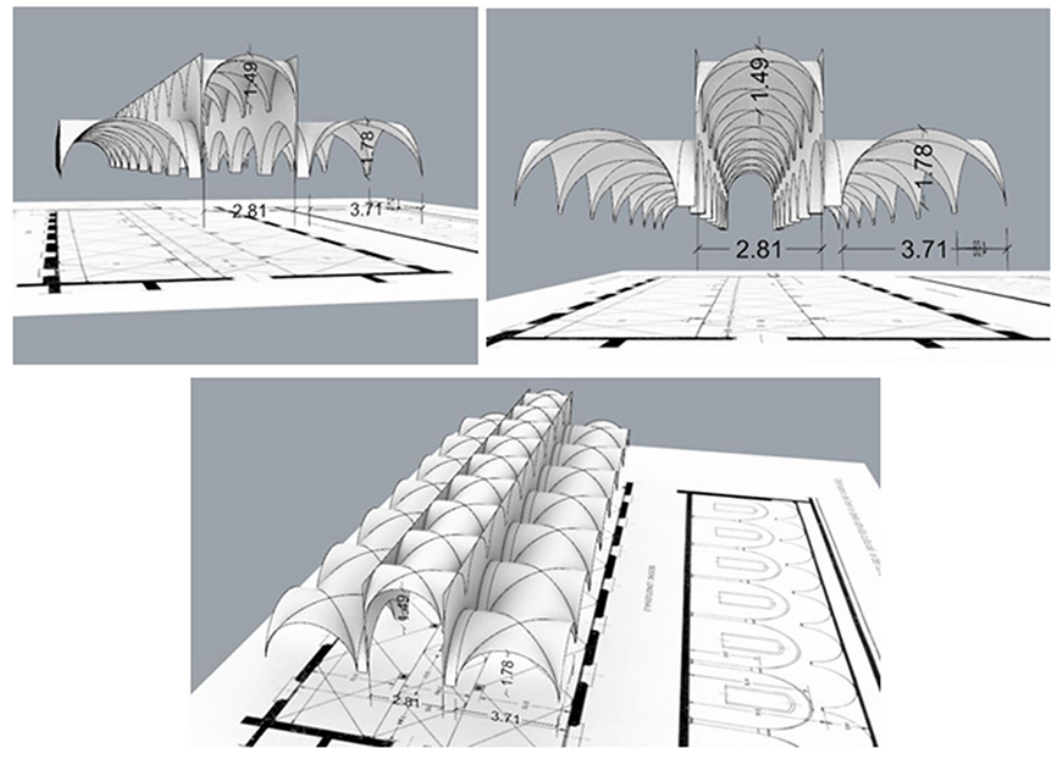

The digital survey reconstruction: the vaults of the Chiostro delle Rane

The opportunity to deal with geometrical interpretations and reconstructions based on the survey of an existing building was addressed for the Chiostro delle Rane and the convent part that together with the old sacristy seems to be attributed to Donato Bramante and that was spared from the bombings of 1943.

The starting point of this study was the geometrical modelling of the Chiostro delle Rane, then the cross vaults shape study was deepened and finally, the old sacristy Vault reconstruction was realized. The 3D measurements were conducted using a Terrestrial Laser Scanner (TLS) [Bolgnesi, Fiorillo 2019], and the different scans (45 in total) were registered in the same coordinate system using a cloud-to-cloud algorithm in order to obtain a complete $3 d$ points model.

However, these two architectural elements (the Chiostro delle Rane and the old sacristy) were segmented from the referenced point model and decimated with a point-to-point distance of $\mathrm{I} \mathrm{cm}$, in order to simplify the management of the point cloud in the modelling software. 
The direct modelling based on the 3D measurements of the Chiostro delle Rane vaults was addressed in two ways: on the point cloud and on the polygonal model. The 3D results obtained were also compared with each other, and a next step will be the estimation of the deviation between the real measured vault model and its ideal shape.

The geometry of the cloister is formed by five spans of plastered cross vaults for each side, which are resting on corbels embedded in a white plastered wall. The cloister shape is a regular square and measures $24 \mathrm{~m}$ on each side presents. The geometry of the cross vaults is also regular except for some more complex moulding and capital.TLS has been chosen as the best solution to survey, considering the morphology of the architecture, the necessity to capture the geometric feature of the elements and the uniformity of the vaults' textures (white plaster).

The laser scanner survey was performed using a phase-shift measurement system (Leica HDS700). The scanning resolution was set at $6 \mathrm{~mm}$ at a distance of $10 \mathrm{~m}$, satisfying a graphic $3 \mathrm{D}$ representation according to 1:50 scale (plotting error of $10 \mathrm{~mm}$ ).

The theoretical modelling starts with the geometrical segmentation of the cloud of the cloister, which was decimated with a point-to-point distance of $\mathrm{I} \mathrm{cm}$. The vaults drawn in the Chiostro delle Rane are another example of vaults a cruise perfectly consistent with the vaulted system of the library set on a nearly square base of approximately $3.00 \times 3.10$ m (fig. 4).
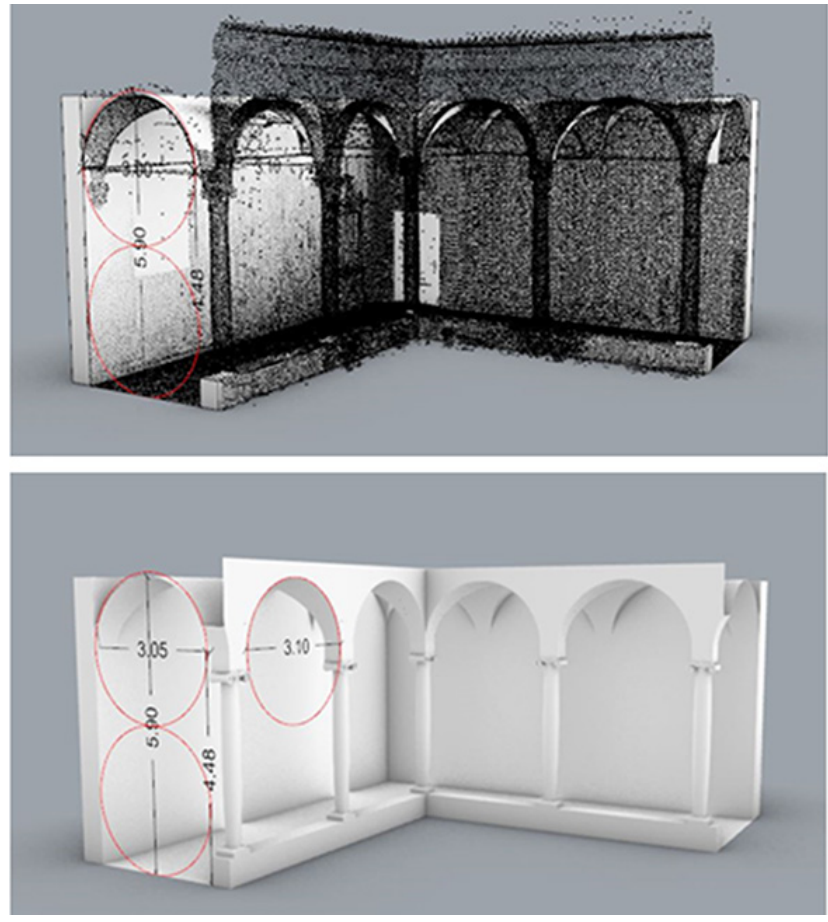

A second option for the passage from the point cloud to the geometrical model deals with the possibility to realize a polygonal model. After considering several software for creating the mesh, the choice was oriented towards Cloud Compare, open-source software for processing point clouds and meshes (which is particularly effective in terms of the possibility of getting meshes with a high level of detail and relatively short processing times).

The workflow for creating the mesh follows several steps:

- the scans of the cloister was imported into Autodesk Recap Pro software, cleaned up and divided into 4 chunks (each corresponding to a quarter of cloister and roughly characterised by 45 million of points) to facilitate subsequent processing; 
- the point cloud's chunks were exported (in .pts format) and then imported separately in Cloud Compare, where it was possible to recalculated normal (information lost during the conversion in .pts). This phase proved to be the most expensive in terms of time, considering that to obtain the information on the normal vectors it was necessary to process each chunk for about $5 / 6$ h;

- once the normal directions have been computed, the "Poisson surface reconstruction" plugin has been used to obtain meshes with a high level of detail, each of which consists of an average of 10 million faces;

- the obtained meshes (exported in.obj) have been optimised in Autodesk Recap Photo (identifying and deleting of all the noised groups of triangles);

- the chunk was then imported into Rhinoceros for visualising and reverse modelling the geometries (each mesh maintained the initial absolute reference system so that no alignment was necessary). The meshes were used to perform reverse modelling of the architectural element to obtain NURBS with high accuracy. The "multiple sections" command was used to obtain curves coinciding with the generating curves of the analysed surfaces. The sections were generated with a pitch of $3 \mathrm{~cm}$ to obtain an element that highlights the imperfections and irregularities of the real surfaces. The NURBS was finally obtained by combining the various sections with the loft command, which made it possible to obtain the cross vaults of the cloister and consider it not only in its geometric conformation but in its physical state of deformation that has occurred over the centuries;

- as a further examination of the degree of accuracy of the geometrical model, it has been transformed into a mesh and it has been imported into Autodesk Netfabb to compare the initial polygonal model with the final one. The result of the comparison was a heat-map, which showed that the maximum error obtained from the meshes' overlapping is never more than $0.03 \mathrm{~mm}$, allowing us to obtain an exact morphology of the actual state of the vault.

\section{The geometrical reconstruction and differences from the digital survey: the vault of the old sacristy}

The last case analysed concerns the vault of the old sacristy of Bramante: once set on a three-circle arch with lunette and equipped with an umbrella closure in the final parts. The Sacristy, together with the cloister, represents one of the Bramantesque elements that were not involved in the bombings of 1943.

Unlike the vaults of the cloister, it is enriched by a rich decorative structure consistent with its general morphology: large areas that represent a starry sky, with stars decorated in relief, stretched between the vaults where the diagonal arches decorated in gold underline the changes in inclination.

The survey of the whole sacristy was performed using the P30 and acquiring II scans: 8 ( 4 close to the left side and 4 close to the right side), taken at a height of about $170 \mathrm{~cm}$ from the floor, I near the apse, also taken at $170 \mathrm{~cm}$ in height, and 2 in the centre of the nave, at a height of about $250 \mathrm{~cm}$ from the floor (this height was necessary to reduce the shaded areas and to acquire a more consistent part of the vault and of the wooden furniture surrounding the walls).

The first 9 scans were acquired with a resolution of $3.1 \mathrm{~mm}$ at $10 \mathrm{~m}$, the other two with a resolution of $1.6 \mathrm{~mm}$ at $10 \mathrm{~m}$. The photos were captured in full-dome mode in HDR with a resolution of $1920 \times 1920$ pixels for a single frame. In order to allow a more reliable chromatic reconstruction, together with the laser scans, a photographic dataset of all the decorated surfaces (the vault, the apse, the wardrobes) was collected. The laser scanner data were then processed within Cyclone, which aligned the individual point clouds with the cloud-to-cloud method (target-less approaches).

As already specified for the cloister, the sacristy point model was segmented from the whole model and decimated with a point-to-point distance of $\mathrm{I} \mathrm{cm}$. The first section of this decimated vault was obtained in order to understand the real geometry of the main 
arch. For the main curvature of the vault, the theoretical model identifies a major arch derived from the construction of a 3-circle arch, visible to the naked eye especially near the sides of the arch.
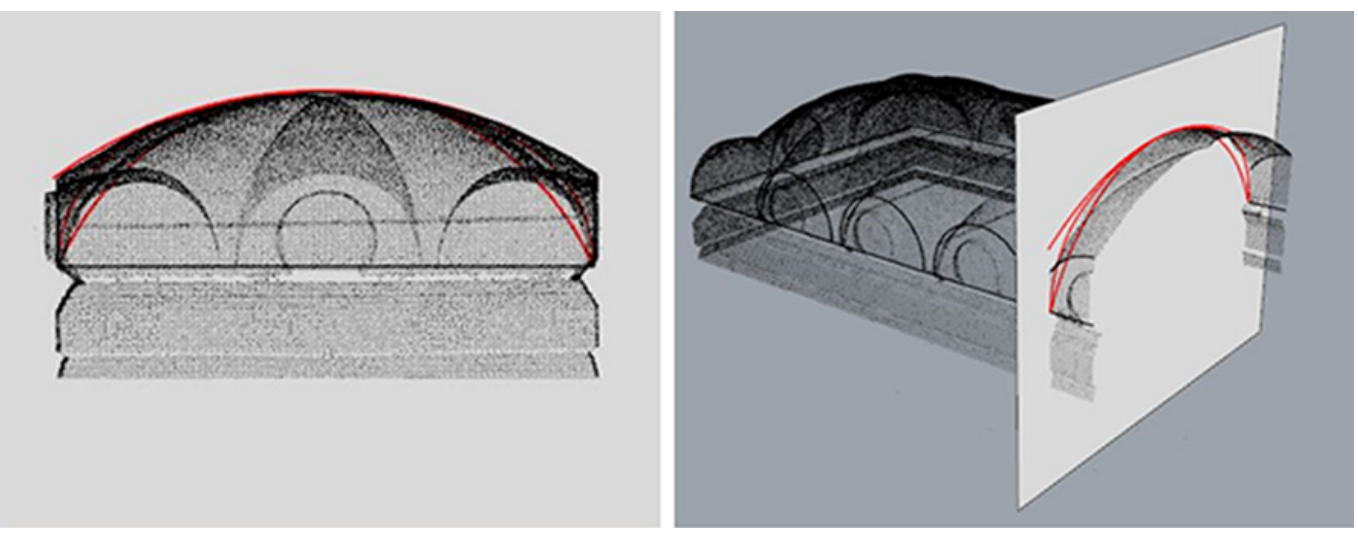

However, when this construction, that seems the most suitable, is compared with the real point cloud specifically in the intersections with the lunettes and related springer, easily traceable on the point cloud model, (in construction from the lunettes) it gives rise to a visible deviation in the modelling of about $10 \mathrm{~cm}$. The same procedure was adopted modifying the rays of the two lateral circles as well as by trying a construction with a single arc of a circle, which in this case finds a pro-directional relationship with the environment of the sacristy. However, even in this case the modelling did not find precise confirmation in the survey carried out; the gap between the two curves is easily identifiable in figure 6 on the left (a), the overlapping of them on the right (b).

Fig. 6. Geometrical model of the vaults of the old sacristy. On the left the main curve, derived from a 3-circle arch, in the middle one single circle middle one single circle
(the lowest) for the main (the lowest) for the main
vault and a wider for the vault and a wider for the
lunette, the third showing the differences among the first and the second method of tracing.

Fig. 7.Theoretical model of the vaults of the old sacristy. On the left the main curve, derived

from a 3-circle arch and lunette, on the right one single circle for the main vault and a wider for the lunette.
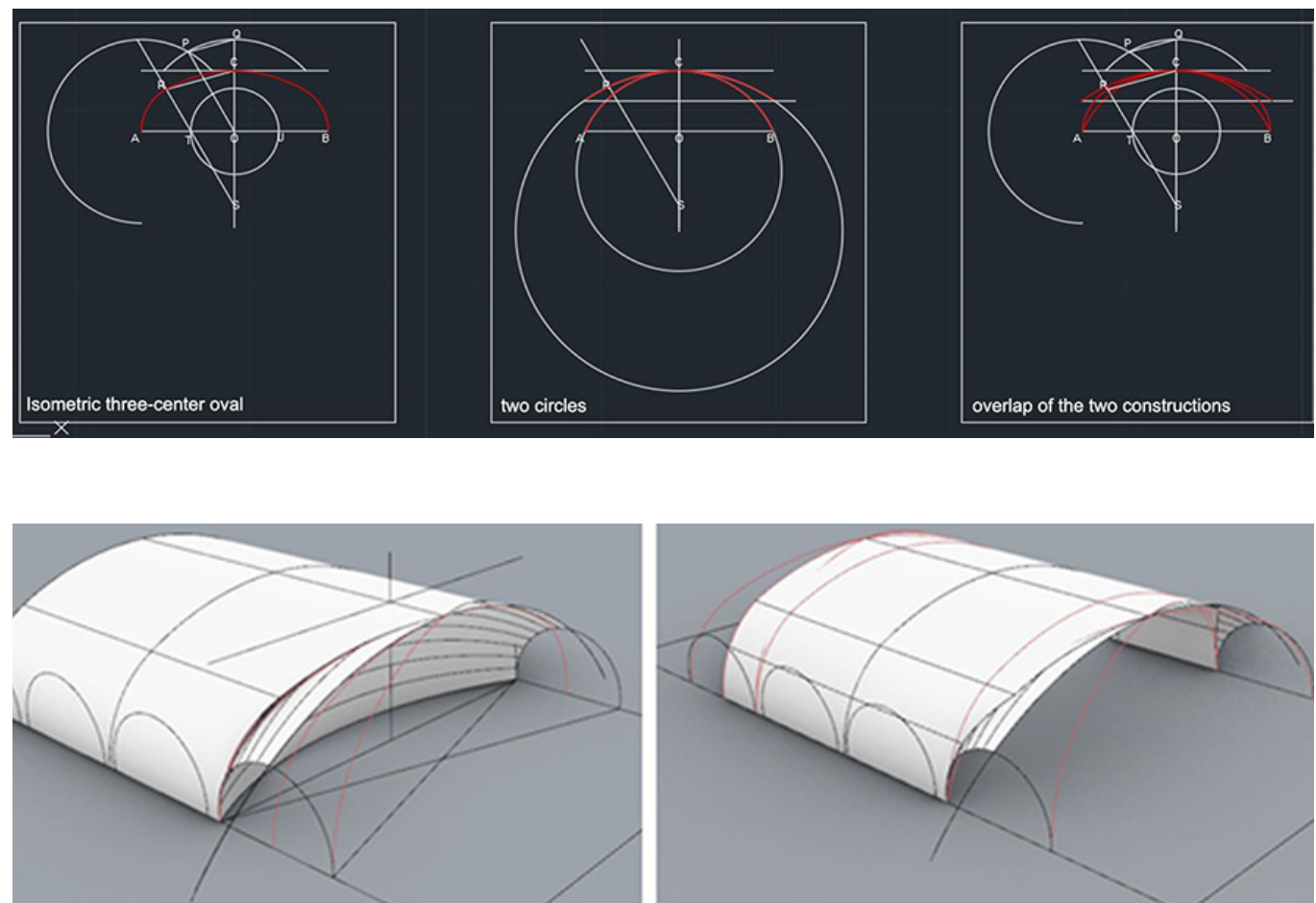


\section{Conclusion}

This monument offers an overview of the whole production cycle of vaulted systems built in a certain amount of years in the same place; it goes back from construction to design and ideation through a geometrical analysis. Graphical analyses and reconstructive digital models allowed highlighting the role of geometry in the Milanese Renaissance and the logic of shapes' composition at the basis of them. In this paper, we considered different survey data and simple geometrical rules.

The research now will be implemented with more 3D specific geometric modelling (direct and parametric [Tommasi et al. 2016] to understand if we can consider Renaissance geometry rules verified from construction on site.

\section{References}

AA.W. (1983). Santa Maria delle Grazie. Cinisello Balsamo: Amilcare Pizzi Arti Grafiche. Banca Popolare Di Milano.

Bolognesi Cecilia, Fiorillo Fausta (2019). Analysis of Historical Documentation Accuracy Aimed to Semantically-Enriched 3D Representations. In Belardi Paolo (ed.). Reflextions: the art of drawing/the drawing of art. Proceedings of the 4Ith International Conference of Teachers of the disciplines of the Representation. Perugia, 19-21 september 2019, pp. 402-408. Roma: Gangemi Editore.

Calvo López José, Rabasa Díaz Enrique (20 l 6). Construcción, dibujo y geometría en la transición entre Gótico y Renacimiento. In Artigrama, 31 , pp. 67-86.

Capone Mara, Campi Massimiliano, Catuogno Raffaele (2015). Gothic churches in Paris St Gervais et st Protais. In Int. Arch. Photogramm. Remote Sens. Spatial Inf. Sci., XL-5/W4, 20 15, pp. 423-430 <https://doi.org/ I 0.5 194/isprsarchives-XL-5-W4-423>.

Corazzi Roberto, Bertacchi Silvia (20I5). Documentazione dell'intradosso della Cupola di Santa Maria del Fiore a Firenze tramite rilevamento fotogrammetrico Structure from Motion (SFM). In DisegnareCon, 8/14, pp. I- I2.

Gattico Girolamo (2004). Descrizione succinta e vera delle cose spettanti alla chiesa e convento di Santa Maria delle Grazie e di Santa Maria della Rosa e suo luogo, et altre loro aderenze in Milano dell'Ordine de'predicatori con due tavole in fine. Milano: Ente raccolta Vinciana.

lannizzaro Vincenzo et al. (20I2). The domes of the Amalfi Coast: survey and digital representation of complex shapes. In: Domes in the world. International Congress Proceedings. Firenze: Nardini Editore, 20 I 2, pp. I - I 2.

López-Mozo Ana, Senent-Domínguez Rosa (2017). Late Gothic Asymmetrical Diamond Vaults in Spain. In Nexus Network Journal, 19, pp. 323-343.

Martelli Gisberto (1980). II reflettorio di Santa Maria delle Grazie in Milano e il restauro di Luca Beltrami nell'ultimo decennio dell'Ottencento. In Bollettino d'Arte Roma, 1980, 65.8, pp. 55-72.

Mezzanotte Paolo, Bascapè Giacomo C. (1968). Milano nell'arte e nella storia. Milano: Carlo Bestetti.

Navarro Camallonga Pablo, Rabasa Diaz Enrique (20 I 8). Vaulted Ceilings Built Like Arches. In The Architectural Works of Baldomar. Ega-Revista De Expresion Grafica Arquitectonica, 32, pp. I42- 153.

Pica Agnoldomenico, Portaluppi Piero (1938). Le Grazie. Roma: Casa Editrice Mediterranea.

Spallone Roberta (2019). Geometry of vaulted systems in the treatises by Guarino Guarini. In EGE Revista de Expresión Gráfica en la Edificación, [S.I.], n. II, pp. 79-93.

Tommasi Cinzia, Achille Cristiana, Fassi Francesco (2016). From point cloud to BIM: a modelling challenge in the cultural heritage field. In Int. Arch. Photogramm. Remote Sens. Spatial Inf. Sci., XLI-B5, 20 I 6, pp. 429-436.

Tucci Grazia, et al. (2019). Ground Based 3D Modelling (Photogrammetry and TLS) - Survey, Documentation and Structural Assessment of XX Century Cultural Heritage In India - A Case Study of the Masonry Vaults in Dehradun. In Int. Arch. Photogramm. Remote Sens. Spatial Inf. Sci., XLII-2M I I, pp. I I05- I I I.

\section{Authors}

Cecilia Bolognesi, Politecnico di Milano, cecilia.bolognesi@polimi.it

Fausta Fiorillo, Politecnico di Milano, fausta.fiorillo@polimi.it

To cite this chapter. Bolognesi Cecilia, Fiorillo Fausta (2020). Survey and modelling for a theoretical reconstruction. In Arena A., Arena M., Brandolino R.G., Colistra D., Ginex G., Mediati D., Nucifora S., Raffa P. (a cura di). Connettere. Un disegno per annodare e tessere. Atti del $42^{\circ}$ Convegno Internazionale dei Docenti delle Discipline della Rappresentazione/Connecting. Drawing for weaving relationships. Proceedings of the 42 th Internationa Conference of Representation Disciplines Teachers. Milano: FrancoAngeli, pp. I39-146. 